H O OFDSTK VI.

\title{
AGRARISCHE TOESTANDEN.
}

Het Portugeesch Gouvernement was, gelijk bekend is, er steeds op uit om van zijne overzeesche bezittingen zóóveel voordeel te trekken als slechts mogelijk was.

Brazilië was het land, dat der Regeering goud en diamanten moest leveren; de landbouw werd er weinig aangemoedigd, ja eerder tegengegaan. De meeste indische producten, o. a. de indigo en de koffie mochten niet geteeld worden, omdat men vreesde dat de invoer van die producten uit Portugeesch Indië zou verminderen.

Om die reden was Minas Geraes om haren mineralen rijkdom de meest bekende en de volkrijkste provincie van Brazilië. Voor men de kustprovinciën Rio de Janeiro en Espirito Santo begon te bebouwen, was Minas Geraes reeds door bergwegen aan de hoofdstad van het rijk verbonden.

De gouddelving was, evenals het exploiteeren van de diamantmijnen, een monopolie van de Regeering. Evenwel waren er vele gelukzoekers, die steelsgewijze goud voor eigen rekening gingen zoeken. Van werkelijken mijnbouw was evenwel geen sprake. Men ontgon slechts hier en daar de rijkste aderen.

Men koloniseerde niet methodisch van uit eenige punten van de kust, maar verspreidde zich bij kleine benden over de gansche oppervlakte van het land, uitsluitend met het doel goud of edelgesteenten te gaan zoeken.

De Regeering ging die gouddelvingszucht tegen, minder met het oog op den landbouw dan wel om haar monopolie te handhaven en te beschermen.

Zoo gebeurde het dat een zeker avonturier, die als gouddelver eenigen naam had gemaakt, zich schuil moest houden voor de hem zoekende politie. Van Minas vluchtende, ging hịj in de Ur-bosschen van de provincie Rio de Janeiro, waar hij zich veilig waande, omdat de streek nog weinig bekend en 
wegens gemis aan verbindingswegen van uit de hoofdstad niet te bereiken was. Om zijne gevlekte hand is hij in de provinciale geschiedenis van Rio de Janeiro meer bekend onder den naam van "Māo de Luva". Hij verschool zich in de bosschen van Cantagallo, waar hij zijn oud bedrijf ter hand nam en ijverig naar goud zocht. In hoeverre hem de gouddelving dáár wat opbracht, weet men niet, maar zeker is het dat verscheidene zijner vroegere makkers, voor de politie moetende vluchten, zich bij hem voegden en met hem den grondsiag legde van de tegenwoordige stad Cantagallo.

De Regeering, vernemende dat Māo de Luva zich in die streken ophield, zond een detachement politiesoldaten om hem gevangen te nemen. Over de provincie Minas Geraes kwamen zij al zoekende in het Cantagallosche. Zij zouten evenwel onverrichter zake teruggekeerd zijn, ware het niet dat zij door een toeval, door het gekraai van een haan, de vestiging onzer vluchtelingen op het spoor kwamen. Naar aanleiding van dit feit kreeg de plek den naam van Cantagallo of Hanengekraai.

Algemeen wordt het er voor gehouden, dat het aan die gebeurtenis te danken is, dat het centraal gedeelte van de provincie Rio de Janeiro meer bekend en eindelijk ontgomnen werd.

Het grondbezit gaf reeds spoedig nà de onafhankelijkheidsverklaring van Brazilië tot tal van moeielijkheden en verwikkelingen aanleiding. Zulks kan geen verwondering wekken, indien men nagaat op welke wijze de eerste grondverdeeling plaats vond.

Naar alle waarschijnlijkheid was het om in het nieuw ontdekte en in bezit genomen land een aan de vaderlandsche regeering door de hechte banden van het eigenbelang verknochte land-aristocratie te hebben, dat het Portugeesche Hof zoo mild was met het wegschenken van groote uitgestrektheden grond aan ambtenaren, die zich verdienstelijk hadden gemaakt en daarom aanspraak konden doen gelden op de gunst der Regeering. Van het opmeten en vastleggen van die landcomplexen aan bepaalde gemakkelijk terug te vinden punten kon toen natuurlijk nog geen sprake zijn. Men vergenoegde zich dus met den schenkingsbrief, waarin in zeer ruwe trekken de ligging van het perceel werd aangegeven.

Deze wijze van uitgifte van gronden gaf in die koloniale tijden zelden aanleiding tot verwikkelingen, eerstens, wijl die landcomplexen, gelijk gezegd, groote uitgestrektheden besloegen, 
zoodat de eigenaars er van zich niet over de juiste af bakening hunner grenzen behoefden te bekommeren, ten andere, wijl die eigendommen weinig waarde vertegenwoordigden wegens gemis aan middelen om ze in cultuur te brengen. Nog in het laatst van de eerste helft van deze eeuw werden groote uitgestrektheden grond overgedaan voor een jachtgeweer en eenig contant geld.

De geheele provincie Rio de Janeiro en een groot deel van Espirito Santo werden indertijd als leengoed afgestaan aan deu portugeeschen admiraal Martim Affonso de Souza, ter belooning van de vele en gewichtige diensten door hem bewezen bij de ontdekking van Brazilië.

$\mathrm{Na}$ de verdrijving der Franschen door den onderkoning van Bahia Men de Sá in 1567 trok de Regeering de provincie weder tot zich en werd zịj als kroondomein tot een van Bahia afhankelijke Capitania verheven. Eerst in 1658 werd zij feitelijk van Bahia onafhankelijk verklaard en gebracht onder het bestuur van een afzonderlijken Gouverneur-Generaal, aan wien men evenwel eerst in 1763 den titel en de rechten schonk welke aan den onderkoning van Bahia waren verleend. De laatste onderkoning van Rio de Janeiro, de markies de Noronha, meer bekend onder den naam van graaf dos Arcos ', legde in 1808 zijn ambt neder bij de aankomst van den prins regent Johann VI.

$\mathrm{Na}$ de onafhankelijkheidsverklaring van Brazilië werden de gouvernementsgronden in de verschillende provinciën in kleinere uitgestrektheden, in zoogenaamde sismarias aan particulieren geschonken of verkocht.

Die sismarias waren echter niet overal gelijk en gelijkvormig. In de provinciën Rio en Minas hadden zij in den regel den quadraat-vorm, terwijl zij in S. Paulo meer langwerpige vierkanten uitmaakten. Men heeft sismarias van 400 en 225 alqueires ${ }^{2}$.

Bij het uitzoekən van die gronden ging men van slechts één bepaald punt uit, zoodat het vierkant vaak naar willekeur om dat punt kon worden verplaatst, naar gelang men zich van grensgronden wilde meester maken. Om grensgeschillen te voorkomen, bleven tusschen de sismarias breede strooken grond open. Op die gronden nu vestigden zich van lieverlede landbouwers, die zonder eenigen wettigen titel van aankomst het bezitrecht daarop uitoefenden.

1 Zie bl. 45.

"Zie voor nadere bizonderheden het hoofdstuk "koftiecultunr." 
Aangezien het Gouvernement aan die grond-usurpatie paal noch perk stelde en die kleine landbouwers door de eigenaren van de sismarias met rust werden gelaten, zoolang zij de grenzen van die landgoederen eerbiedigden, verkregen zij eindelijk door verjaring de rechten, welke de groote landheeren door aankoop of schenking hadden erlangd. Later zijn die bezitrechten door het Gouvernement erkend.

Op die wijze ontstonden naast of juister gezegd tusschen het groot landbezit de kleine landgoederen of posses.

Men schijnt het onderscheid in bezits-oorsprong nog altijd in acht te nemen, want vaak hoorde ik in de binnenlanden spreken van $\frac{1}{4}, \frac{1}{2}$ of $1 \frac{1}{2}$ sismarias en van groote of kleine posses. Zelden b. v. zal men zeggen: inijne bezittingen zijn zooveel hectaren of alqueires groot, maar steeds spreken van een fazenda of onderneming van zóóveel sismarias en zóóveel posses.

Het spreekt van zelf, dat de beste gronden aan de sismarias-bezitters toebehooren. Het klein-landbezit treft men dan ook meer in de laaglanden, in de serra abaixo, terwijl in de hoogvlakten, in de serra acima het groot landbezit de overhand heeft. Evenwel begint ook dáár door schenking, erfenis en verkoop het grootlandbezit te verminderen. In het noordoostelijk gedeelte van de provincie Rio de Janeiro treft men nu reeds vele kleine ondernemingen, - fazendoles en sitios genaamd, - die niet grooter zijn dan 25 tot 50 hectaren en welker eigenaren het landbouwbedrijf uitoefenen met 5 tot 10 slaven.

Toen men eindelijk, omstreeks het midden van deze eeuw, begon in te zien dat, tegelijk met de onderdrukking van den slavenhandel, ook maatregelen dienden getroffen te worden om de vrije immigratie aan te moedigen en te bevorderen, besloot de Regeering het noodige te beproeven om in den chaotischen toestand waarin het landbezit zich bevond eenige verbetering te brengen.

Bij de wet van 18 September 1850 (Lei das terras), welke echter eerst ruim 3 jaren later bij reglement van 30 Januari 1854 ten uitvoer werd gebracht, trachtte de Regeering:

10. eene algemeene regeling te verkrijgen van het particuliere landbezit, door de verschillende ingewikkelde grenskwestiën uit den weg te ruimen, en tevens om

20. met eenige juistheid te weten te komen wat privaat- en wat staats-eigendom was, aangezien zij de domein-gronden ten 
behoeve van de kolonisatie wenschte te doen opmeten, verleelen en verkoopen aan de immigranten.

Ter uitvoering van dit reglement werd eene afdeeling opgericht bij het Ministerie van Binnenlandsche Zaken (repartiçāo geral das terras publicas), welke echter later, in 1861 , bij het toen opgerichte Departement van Landbouw, Handel en Openbare Werken werd ingedeeld. Zij werd belast met de zorg voor en de opmeting, de verdeeling en den verkoop van de staatsdomeinen (terras devolutas) en tevens met het toezicht op de kolonisatie. Tot haar behooren de inspecteurs, die den geodesischen arbeid in de verschillende provinciën moeten leiden. Een reglement voor de daarmede belaste ingenieurs schrijft voor, op welke wijze de opmetingen en opmamen praktisch moeten worden uitgevoerd; bij die uitvoering moet hoofdzakelijk gelet worden, dat de détail-opmetingen van de terras devolutas zich moeten aansluiten aan een voorafgaande meridian-bepaling en bovendien zóódanig moeten plaats hebben, dat men landeomplexen verkrijgt van 2 leguas in het vierkant. '

Deze vierkante perceelen worden territorios genoemd en moeten in twaalf gelijke en gelijkvormige deelen of lotes gesplitst worden, wier grenzen duidelijk en met nauwkeurigheid moeten worden afgebakend.

De verkoop van die "lotes" geschiedt naar gelang van de aanvraag en na advies van den chef van de "repartiçāo geral das terras publicas", hetzij ondershands dan wel bij publieke veiling tegen comptante betaling. Zij worden naar hoedanigheid en ligging verdeeld in vier categoriën, die tegen vastgestelde prijzen, namelijk $\frac{1}{2}, 1,1 \frac{1}{2}$ en 2 reis per vierkante braça kunnen worden verkocht. Volgens deze basis komt één hectare te staan op $f 1,24, f 2,48, f 3,72$ en $f 4,96$.

Daar een "lote" of uitgestrektheid van 1452 hektaren in vierdeelen gesplitst kan worden, kunnen ook de kleine kolonisten op die wijze grondeigendom verkrịjgen.

Ofschoon deze "Lei das terras" volstrekt geen aanspraak kan maken op volledigheid of volkomenheid, bevat zij toch veel goeds en kan zij nuttig werken, indien zij slechts wordt uitgevoerd. Tot heden is zij echter meer een wet "para inglez ver", gelijk men in Brazilië dergelijke, in de praktijk schier onmogelijk toetepassen wetten en bepalingen noemt.

${ }^{1}$ Legua brazileira $=3000$ braças $=6,6$ kilometers. 1 braça $=2,2$ meters. 1 milreis $=f 1,20$. 
Zoo bv. wordt in die wet bepaald: dat alle grondbezitters, zoowel zij die een titel van schenking of aankomst hebben, als de bezitters van geusurpeerde gronden of "posses" verplicht zijn, binnen 2 jaren na de dagteekening van het reglement van 1854, hunne landen te doen opmeten en voorts dat geene ongemeten gebleven stukken grond mogen worden belast of verdeeld. Om het recht te hebben zijne gronden te doen opmeten, moet men het bewijs leveren of dat men een wettigen titel bezit, ò dat men den grond zonder rechtstitel reeds gedurende minstens 4 jaren heeft bewoond of dat men zijn grond ter goeder trouw bezit krachtens koop van de $2 \mathrm{e}$ of $3 \mathrm{e}$ hand. Bij die wet werden de pastoors van de betrekkelijke kerspelen of freguezias verplicht de eerste grondregisters aan te leggen, waaruit later de algemeene registers zouden worden tesamengesteld.

Gelijk te verwachten was in een land als Brazilië, waar schier alles nog geregeld moest worden en waar in de praktijk het voornaamste werk - het aanhouden van vertrouwbare registers - op de geestelijken rust, bleef de wet zoo goed als onuitgevoerd. Tot nu toe, dat wil zeggen 30 jaren na die fundamenteele wet, weet men nog niet hoe groot het publiek domein is, waar de territorios en lotes liggen, en welke uitgestrektheid door particulieren is in beslag genomen. Slechts dit weet men met zekerheid, dat behalve het thans nog door de indianen bewoond gebied in de binnenlanden van S. Paulo, in de geheele koffie-area van Centraal Brazilië de Regeering geen palm breed woesten grond bezit, maar alles aan partikulieren toebehoort.

Ten bewijze hoe wonderlijk men in Brazilië nog te werk gaat met de toekenning van concessiën, haal ik hierbij een algemeen in Rio bekend feit aan.

$\mathrm{Nu}$ eenige jaren geleden werd nog aan den heer Joāo José Fagundes de Rezende e Silva voor 90 jaren verleend het uitsluitend recht om de mijnen te ontginnen, welke zich mochten bevinden op eene nitgestrektheid van $1000 \square$ leguas of 43,560 vierk. kilometers grond nabij de bronnen van de Tocantins, Xingú, Maranhāo en Cayapó-rivieren. Tot nu toe heeft de heer de Rezende te vergeefs getracht, ook in Engeland, om geld te krijgen voor zijne reusachtige plannen van mijnbouw en kolonisatie. Om die reden is hij thans meer bekend onder den spotnam van Baron van Cayapó. 